\title{
THE SNOW-BED IN Y FFOS DDYFN
}

By S. E. AsHMoRe

THE last report refers to the winter $1947-48$ and is contained in a paper ${ }^{1}$ which summarizes the observations of J. R. Gethin Jones between I879 and 1919 and gives details of the resumption of the work in 1947 . The winters of $1948-49$ and $1949-50$ were mild and the snow disappeared early and on dates which are only approximately known. However, many observational data are available for the winter $195^{0-5} \mathrm{I}$, which was notable for its length and heavy snowfall.

The first snow cover on Carnedd Llywelyn was on 28 October 1950, and it melted in a few days. On 12 November there was a further snowfall, which remained and proved to be the beginning of the longest snow cover since I879. December was the coldest month of the winter with almost continuous heavy additions of snow, and by the beginning of $195^{1}$ the accumulation

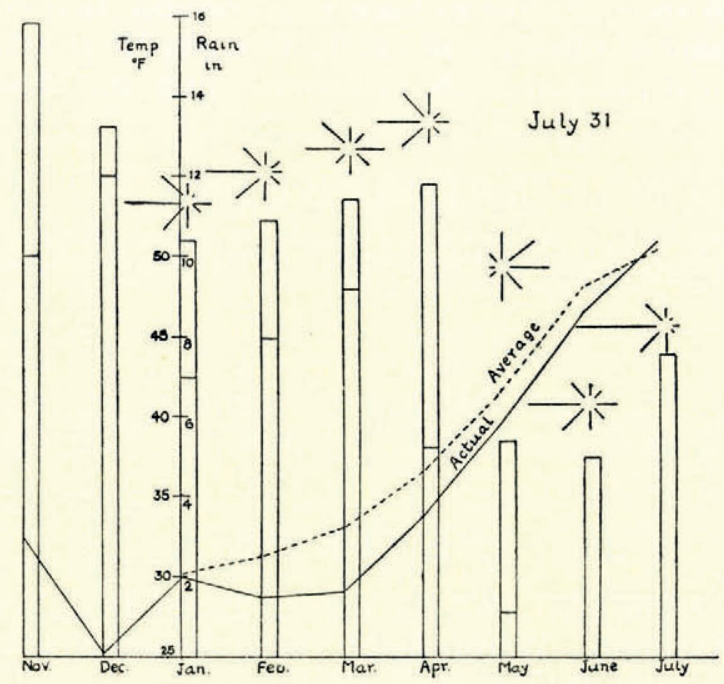

Fig. .

was well in advance of that in the "record" year 1879 . January was not notably severe, and on a visit in mid-month during a mild spell the gully could not be found. It must have been full and heaped up over the general level. The signpost was invisible, and it was later found to have been snapped off, apparently by snow-movement (it has been re-erected as a guide to visitors, whose observations will be welcomed by the writer). The gully was impossible of access for a long period after this; slight thaws early in March and in mid-April were followed by further heavy snow. Considerable melting did not occur until May, and was arrested at intervals by snowfalls, the last of these being on 16 June. Fig. I (above) gives a chart of weather conditions at y Ffos Ddyfn. This shows for each month a wind-rose, a block to represent rainfall in inches and a line across it to represent feet of snowfall on the same scale. Average and actual monthly temperatures are given as curves. It is estimated that $52 \mathrm{ft}$. ( $15.8 \mathrm{~m}$.) of snow fell during the winter, of which only about Io $\mathrm{ft}$. $(3.0 \mathrm{~m}$.) had melted up to the end of March; this is far in excess of the 1879 fall, and would nearly fill the gully without drifting. Temperature was below average throughout the life of the snow-bed until the last ten days of July. 
On 21 July the snow-bed measured about $120 \mathrm{ft}$. $(36 \mathrm{~m}$.) in length with an average width of ro $\mathrm{ft}$. $(3.0 \mathrm{~m}$.), the maximum depth being about $6 \mathrm{ft}$. $(\mathrm{r} \cdot 8 \mathrm{~m}$.). A photograph taken at the time is almost identical with one taken on 29 June I9 1o by Gethin Jones, ${ }^{2}$ including the ripples with dirt on the crests and the position of the patch of softer clean snow near the head. The snow was hard, and from its appearance it was confidently expected to last into mid-August and break the 1879 record. But the next ten days were warm, and on another visit paid on $3 \mathbf{I}$ July, the last of the snow had vanished. This had obviously occurred only a few hours previously, as the melt water was still saturating a part of the ground amid dry surroundings. It was these warm ten days, the like of which did not occur in 1879 , which caused such rapid ablation at the end.

There has been previous discussion of factors conducive to the long survival of this particular snow-bed, such as heavy accumulation, low spring temperature and a dry early summer with little warm rain. A further factor, already suspected and brought out in the present review, is a low frequency of south and south-east winds, the only ones able to blow up the gully and cause excessive sublimation during the late spring and early summer.

Grateful acknowledgement is made to those who provided data:-The British Electricity Authority; the Meteorological Office per Mr. S. T. Tunstall; Messrs. Glyn Roberts and W. S. Parrott; also to those who took part in the field work, particularly Messrs. Alex Williams and John Whiteley.

\section{R E F E R E N C E S}

1. Ashmore, S. E. Late Surviving Snow-Bed on Carnedd Llywelyn. Fournal of Glaciology, Vol. 1, No. 4, 1948, p. 205. 2. Jones, J. R. Gethin. The Spot in England and Wales where snow lies latest. British Rainfall, 1909, p. 5I.

\section{R E V I E W S}

EISZEITALTER UND GEGENWART. (Ice Age and Present Day.) Year book of the Deutsche Quatärvereinigung. Oehringen, Württemberg: Verlag Hohenlohe'sche Buchhandlung Ferd. Rau. Vol. I, 1951, 192 pages, 36 illustrations. 12DM.

AFTER protracted difficulties German Quaternary research has again produced a publication of its own with the aid of the Notgemeinschaft der deutschen Wissenschaft. The Deutsche Quartärvereinigung was formed in 1948 in order to enable geologists, geographers, biologists, students of prehistory and other research workers to meet and work together on such questions as the Pleistocene and the development of climate, soil vegetation and the history of Man up to the geological present. The task of uniting these many and various subjects in the sphere of Quaternary research, where stimulation from every angle was needed, was to be expressed in the name of this new periodical.

The first conference of the Quartärvereinigung was held in October 1948 in Hanover; a great number of papers read there are included in the present volume. Further conferences were held in $195^{\circ}$ in Munich and in $195 \mathrm{I}$ at Mainz, and will be reported in later issues.

In the introduction the editor, Professor P. Woldstedt of Hanover, writes of the tasks and the aim of Quaternary research, ending with the desire for a world-wide union of Quaternary research workers, in the same way as was attempted by the International Quaternary Union formed in Copenhagen in 1928. The contents of the year book range from geological, geomorphological and palaeoclimatological investigations to anthropological and archaeological themes. J. Büdel gives 